\title{
EKSPATRIACJA AKADEMICKA JAKO PRZEJAW INTERNACJONALIZACJI UCZELNI
}

DOI: 10.33141/po.2019.10.03

\section{Sylwia Przytuła}

\section{Wprowadzenie}

G lobalizacja oraz jej wielopłaszczyznowe konsekwencje w obszarze ekonomicznym, społecznym, kulturowym, edukacyjnym doprowadziły do zwiększenia międzynarodowej mobilności wśród przedstawicieli biznesu i edukacji (Trembath, 2016, s. 112).

Wiele krajów próbuje przyciągnąć wykwalifikowanych pracowników z zagranicy, którzy są gwarantem rozwoju gospodarki opartej na wiedzy i źródłem dobrobytu gospodarczego (Flisi i in., 2016). Dotyczy to wysoko wykwalifikowanych migrantów (Sulkowski i in., 2019), a także ekspatriantów, którzy są „pasem transferowym” w przekazywaniu wiedzy pomiędzy organizacją macierzystą a goszczącą (Przytuła i in., 2018). Naukowcy są reprezentantami ekspatriantów o wysokim statusie.

Internacjonalizacja stała się wyzwaniem oraz priorytetem strategicznym także w działalności uczelni wyższych (Domański, 2017) i jest kolejnym obszarem, który wzmacnia tradycyjne kamienie węgielne uniwersytetów, czyli badania (research), nauczanie (teaching) oraz służbę publiczną (public service) (Gao i in., 2015). Dlatego także w tym sektorze zauważa się rosnącą mobilność międzynarodową akademików oraz kolejny etap walki o talenty (war for talents) i zabieganie o naukowców o największej rozpoznawalności międzynarodowej (top performers).

Celem tego artykułu, o charakterze teoretyczno-poznawczym, jest scharakteryzowanie nowej grupy pracowników międzynarodowych, jakimi są ekspatrianci akademiccy, na tle procesów internacjonalizacji uczelni wyższych. W pracy określono kryteria definicyjne dla tej grupy pracowników międzynarodowych, jak również wskazano motywy, które skłaniają naukowców do podejmowania misji zagranicznych ${ }^{1}$.

Literatura na temat szkolnictwa wyższego koncentruje się na internacjonalizacji systemów edukacji (Altbach i in., 2010, s. 19), w szczególności na rozwoju międzynarodowych sojuszy strategicznych między uniwersytetami (Sułkowski, 2018, s. 8) oraz mobilności wśród studentów. Niewiele wiadomo o doświadczeniach mobilnych naukowców na arenie międzynarodowej (Trembath, 2016, s. 112). Ekspatriacja akademicka jest coraz bardziej powszechna wśród naukowców. W tym kontekście zarządzanie tą grupą pracowników międzynarodowych staje się bardziej złożone i powinno być lepiej zbadane. Zarządzanie ekspatriantami akademickimi obejmuje etap preparacji, czyli przygotowania misji zagranicznej, rekrutacji, selekcji, szkoleń przygotowujących do pracy w zagranicznej jednostce, określenie warunków wsparcia przez uczelnię macierzystą dla wyjeżdzającego pracownika. Etap ekspatriacji to wyjazd i pobyt za granicą obejmujący dostosowanie do nowych warunków wykonywania pracy, adaptację kulturową i społeczną dla akademika i członków jego rodziny. Repatriacja, czyli powrót do macierzystej uczelni po długotrwałej misji, oznacza określenie na nowo warunków współpracy i sposobów ewaluacji osiągnięć naukowych.

Wprowadzenie terminu „ekspatriant akademicki” stanowi niewątpliwie wkład teorioznawczy $\mathrm{w}$ tematyce ekspatriacji, a określenie kryteriów definicyjnych tych pracowników i ich motywów skłaniających do wyjazdów zagranicznych wzbogaca ponadto wymiar aplikacyjny nauk o zarządzaniu - pozwala bowiem na właściwy dobór grupy respondentów w badaniach empirycznych. Ponadto kwestie ekspatriacji naukowej, zasygnalizowane w niniejszym artykule, mogą przyczynić się do rozwiązania wielu problemów zarządzania polskimi uczelniami $\mathrm{w}$ dobie internacjonalizacji, które wykazują w swoich badaniach nieliczni polscy badacze.

\section{Rodzaje pracowników międzynarodowych}

W ysoko wykwalikowani pracownicy są kluczowym elementem przewagi konkurencyjnej organizacji (Flisi i in., 2016). Coraz częściej także uczelnie wyższe koncentrują się na pozyskiwaniu międzynarodowej kadry naukowców, mobilnych geograficznie o bogatym doświadczeniu w pracy za granicą (Roberts, 2015).

$\mathrm{W}$ odniesieniu do dotychczasowych ustaleń i definicji pracowników międzynarodowych, co do których większość badaczy z tego obszaru jest zgodna (Mc Nulty, Brewster, 2017), przyjmuje się, że pracownikiem międzynarodowym jest osoba zatrudniona/pracująca za granicą; jej pobyt jest tymczasowy lub z intencją osiedlenia się na stałe w kraju goszczącym; nie jest obywatelem kraju przyjmującego; pobyt jest zgodny $\mathrm{z}$ wymogami prawnymi stawianymi obcokrajowcom w kraju przyjmującym (Mc Nulty, Brewster, 2019). Wyróżnia się trzy typy pracowników międzynarodowych: ekspatriantów (o wysokim, średnim i niskim statusie), migrantów (wykwalifikowanych i niewykwalifikowanych) oraz innych pracowników krótkoterminowych (np. podróżników biznesowych, pracowników wirtualnych) (rys. 1). 


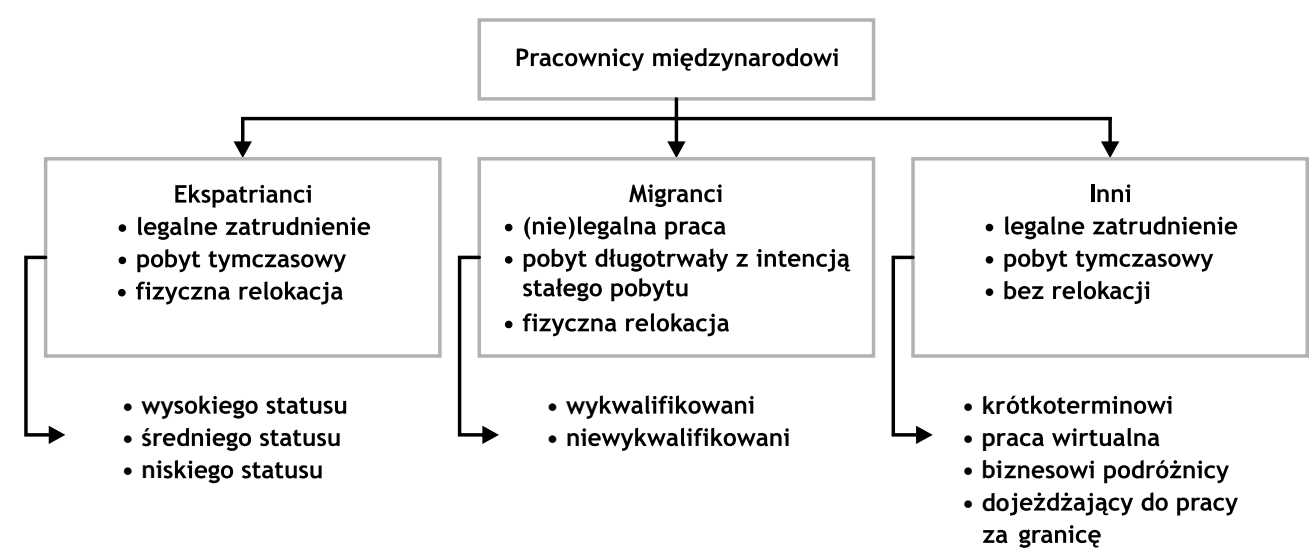

Rys. 1. Typologia pracowników międzynarodowych Źródło: Mc Nulty, Brewster, 2019, s. 15

Ekspatriantem jest osoba podejmująca legalną pracę i mieszkająca w kraju, którego nie jest obywatelem, by zrealizować cele zawodowe. Jej relokacja za granicę odbywa się za pośrednictwem i ze wsparciem organizacji wysyłającej (to tzw. tradycyjny ekspatriant) (Przytuła, 2014) lub jest wynikiem jego własnej inicjatywy (tzw. samoinicjowany ekspatriant) (McNulty, Brewster, 2019; Przytuła, 2018). Wyróżnia się ponadto ekspatriantów o wysokim statusie (są to np. ekspatrianci akademiccy, konsultanci, menedżerowie wyższego szczebla), ekspaci średniego statusu to np. specjaliści IT, pielęgniarki, inżynierowie. Ekspaci niskiego statusu są określani w literaturze jako „ukryci” (hidden expatriates), gdyż poświęca im się niewiele uwagi w badaniach naukowych i są postrzegani raczej jako uzupełnienie lokalnej siły roboczej niż jako pracownicy międzynarodowi. Są to np. kierowcy, opiekunki do dzieci i osób starszych, pracownicy budowy, pracownicy ochrony i sprzątający.

Migranci mają wspólne cechy charakterystyczne także dla ekspatów w zakresie fizycznej relokacji do innego kraju i niektórzy z nich podejmują tam legalną pracę. Jednak różnica między tymi grupami pracowników dotyczy czasu trwania pobytu zagranicznego. Migranci decydują się na wyjazd zagraniczny $\mathrm{z}$ intencją stałego tam osiedlenia się i uzyskania obywatelstwa. Może ona obejmować osoby z różnym poziomem wykształcenia, zarówno pracowników o niskich kwalifikacjach (niewyedukowanych), jak i osoby o wysokim statusie społecznym.

Charakterystyka „innych” na rysunku 1 obejmuje: pracowników na krótkoterminowych misjach, podróżników biznesowych, pracowników wirtualnych oraz osoby dojeżdżające do pracy za granicą (international commuters). Wiele organizacji postrzega „innych” jako atrakcyjną alternatywę dla pozostałych form ekspatriacji ze względu na krótki czas ich pobytu poza miejscem zamieszkania, kontrakt podpisywany jest na zasadach prawa kraju macierzystego pracownika, rodzina delegowanego pozostaje w kraju macierzystym.

Podmiotem zainteresowania $\mathrm{w}$ niniejszym artykule będzie wąska grupa ekspatriantów o wysokim statusie, zwanych ekspatriantami akademickimi.

\section{Ekspatrianci akademiccy - charakterystyka i etos pracy}

E kspatriacja akademicka nie jest zjawiskiem nowym. Już w średniowieczu najwięksi uczeni, poszukując wiedzy $\mathrm{i}$ inspiracji do pracy twórczej, migrowali po całej Europie (Hénard i in., 2012). Z pewnością to fenomen starszy niż ekspatriacja tradycyjna/biznesowa, ale w literaturze przedmiotowej z zarządzania nie znajduje właściwego odzwierciedlenia.

Przepływ ekspatriantów akademickich w ostatnich latach znacznie się zwiększył (Altbach i in., 2010), a udział akademików z innych krajów zatrudnionych na uczelniach wynosi ponad 25\% (Top Universities, 2018), co wynika ze strategii internacjonalizacji zapisanych w misjach uczelni wyższych. Nie bez znaczenia dla tych transferów akademickich jest rozwój języka angielskiego, który stał się lingua franca w międzynarodowej komunikacji naukowej, a dominacja publikacji w języku angielskim (niektórzy autorzy wskazują nawet na „amerykanizację badań naukowych" (Brewster i in., 2016, s. 37)), jest niespotykana od czasów, gdy łacina była językiem akademii w średniowiecznej Europie (Altbach i in., 2010). Także rozwój technologii komunikacyjnych umożliwiających natychmiastowy dostęp do najnowszych wyników badań i osiągnieć naukowych publikowanych na świecie oraz szybkość przemieszczania się pomiędzy krajami pozwala akademikom podejmować pracę $\mathrm{w}$ różnych częściach świata.

W literaturze przedmiotowej poświęconej ekspatriacji proponowane jest wiele definicji wyłaniającej się nowej kategorii pracowników międzynarodowych, jakimi są ekspaci akademiccy (Selmer, Lauring, 2009; Romanowski, Nasser, 2014). Jednak zauważa się zgodność większości autorów co do trzech kryteriów ich definiowania:

1) narodowość akademika jest inna niż kraju goszczącego,

2) zatrudnienie ma charakter długoterminowy choć ograniczony w czasie (kontrakt),

3) naukowiec podejmuje zatrudnienie $w$ instytucjach szkolnictwa wyższego celem realizacji kształcenia, prowadzenia badań i spełniania zadań administracyjnych. 
Ponadto badania dostarczają wiedzy o charakterystyce demograficznej tych pracowników międzynarodowych, które są zbieżne $\mathrm{z}$ charakterystyką tradycyjnych ekspatriantów biznesowych (Brookfield Global Relocation Trends, 2016). Ekspaci akademiccy to w większości mężczyźni (Selmer, Lauring, 2011); żonaci (Selmer, Lauring, 2009), w wieku ok. 40 lat (Trembath, 2016). M. Kwiek (2018) wyróżnia sześć poziomów stratyfikacji w nauce:

1) najbardziej produktywna kadra (academic performance stratification),

2) kadra najlepiej zarabiająca (academic salary stratfication),

3) kadra o największej władzy uczelnianej (academic power stratification),

4) kadra współpracująca $z$ zagranicą $w$ badaniach naukowych (international research stratification),

5) kadra zaangażowana $w$ badania i kadra zaangażowana $\mathrm{w}$ kształcenie (academic role stratification),

6) młoda kadra do 40 lat i kadra starsza (academic age stratification).

Można powiedzieć, że ekspaci akademiccy, w porównaniu z ich lokalnymi kolegami, są pozycjonowani jako: bardziej produktywni (research top performers), lepiej zarabiający (academic top earners), bardziej umiędzynarodowieni (internationalists) i w wieku poniżej 40 lat (academics under 40).

Badacze zauważają też różnice $\mathrm{w}$ zakresie stanowisk i pozycji naukowców $w$ hierarchii akademickiej pomiędzy krajami. W krajach Europy Zachodniej i w USA uniwersytety pozyskują ekspatów akademickich z niższych poziomów hierarchii (assistent profesor, PhD students, young reseracher), natomiast uczelnie azjatyckie i z krajów arabskich zatrudniają kadrę wysoko pozycjonowaną i utytułowaną (full profesor, associate profesor).

Ekspatrianci akademiccy to zarówno ekspaci, jak i naukowcy, jednak łączenie tych dwóch kategorii daje nowy twór, mało zbadany w literaturze (Mc Nulty, Brewster, 2019). Naukowcy to z zawodu myśliciele (Selmer i in., 2017), którzy różnią się od innych pracowników wiedzy tym, że ich praca powinna wpisywać się w etos akademicki (zabarwiony emocjonalnie zespół wartości i norm obowiązujących naukowców i w różnym stopniu przez nich internalizowany, realizowany w takich obszarach triady, jak: kształcenie, badania i służba publiczna). Obszary te wymagają wysokiego poziomu zaangażowania organizacyjnego, na które składają się zaangażowanie emocjonalne, normatywne (osoba pozostaje $\mathrm{w}$ organizacji, ponieważ postrzega to działanie jako najwłaściwsze i moralnie uzasadnione, traktuje je jako rodzaj powinności) i trwania (pracownik wiąże się z organizacją $\mathrm{w}$ celu zaspokojenia własnych potrzeb, $\mathrm{w}$ tym stabilności zatrudnienia, świadczeń socjalnych i innych korzyści) (Allen, Meyer, 1990). Warto dodać, że wiedza nie może być transferowana bez indywidualnego zaangażowania jej posiadacza (Duan i in., 2010). Zaangażowanie natomiast to sposób myślenia (Kmiotek, 2019), a w przypadku akademików jest „uosobieniem stylu życia”, które angażuje i pochłania zasoby emocjonalne, intelektualne, a także fizyczne $\mathrm{w}$ tej pracy, chcąc sprostać wymaganiom, jakie stawiają trzy filary działalności akademii.
Ekspatrianci akademiccy różnią się od naukowców (lokalnych) pracujących w kraju macierzystym, głównie w zakresie „obciążenia poznawczego", jakiego wymaga sama misja zagraniczna. Pobyt naukowca w innym kraju oznacza nowe miejsce pracy, odmienny klimat organizacyjny i reguły zachowań, co wiąże się $\mathrm{z}$ wieloma problemami adaptacyjnymi, które są znamienne także dla innych grup ekspatriantów: separacja rodzinna, stres związany $\mathrm{z}$ podróżowaniem, bezpieczeństwo, problemy zdrowotne, poczucie wyobcowania, niechęć do nawiązywania nowych relacji w kraju przyjmującym (Brookfield Global Relocation Trends, 2016; Selmer i in., 2017).

Powyższe „ryzyka” mogą stanowić znaczące obciążenie psychologiczne dla naukowca i zmniejszenie jego zdolności do wykonywania pracy koncepcyjnej, w szczególności gdy brakuje też emocjonalnego zaangażowania w nowym miejscu pracy (Selmer i in., 2017). Dodatkową barierą jest praca w języku obcym w kraju goszczącym. S. Volk i inni (2014) dowodzą, że wykonywanie złożonych zadań i prac w języku obcym (np. publikowanie, uczestnictwo w konferencjach, prowadzenie badań) zwiększa obciążenie pamięci roboczej mózgu, co prowadzi do obniżenia zdolności heurystycznych (tj. wykrywania nowych faktów oraz znajdowania logicznych powiązań i związków między nimi). Skutkiem takiego obciążenia mogą być skróty myślowe w podejmowaniu właściwych decyzji, stereotypizacja kulturowa w wynikach badań (Lauring, Selmer, 2015). Mimo jednak tak wielu ryzyk, coraz więcej akademików decyduje się na ekspatriację. Co zatem jest motywem podjęcia przez nich decyzji o wyjeździe za granicę? Jakie są oczekiwania związane z karierą naukową?

\section{Motywy podejmowania misji zagranicznej przez pryzmat osobowości mobilnej akademików}

0 ECD opublikował katalog czynników skłaniających do migrowania osoby z wysokimi kwalifikacjami. Są to m.in.: wyższe płace i lepsze możliwości realizowania kariery zawodowej; chęć podniesienia poziomu wykształcenia, realizacji badań naukowych lub odpowiedniego opanowania języka; korzystne warunki instytucjonalne i finansowe za granicą dla naukowców wyrażające się we wsparciu sektora badawczo-rozwojowego i generowaniu wysokiego popytu na jego pracowników; pozytywny klimat dla innowacji (OECD, 2002).

$\mathrm{W}$ literaturze przedmiotowej proponowane są różne metafory określające motywy ekspatriantów akademickich (Selmer, Lauring, 2012):

- eksplorer (explorer) - poszukuje przygody i traktuje misję zagraniczną jako sposobność doświadczania i być może, jako naukowiec, analizowania nowych zjawisk kulturowych;

- uchodźca (refugee) - jest motywowany chęcią ucieczki z kraju macierzystego często z powodu braku możliwości rozwoju kariery na lokalnym akademickim rynku pracy oraz w poszukiwaniu lepszego standardu życia;

- mecenas (mercenary) - jest motywowany zachętami głównie finansowymi ośrodków zapraszających; 
- architekt (architect) - traktuje misję zagraniczna jako kolejny etap rozwoju swojej międzynarodowej kariery naukowej.

Badania w tym zakresie wskazują, że dominujące motywy przemieszczeń naukowców lokują się w rolach mecenasa, eksplorera i architekta. Jednakże rosnąca dynamika mobilności międzynarodowych pracowników w latach 2015-2018 (International Organization for Migration, 2018), która jest rezultatem kryzysu migracyjnego z krajów arabskich i z Chin, dowodzi, że motywy uchodźcze są wskazywane jako kluczowe dla akademików z tych krajów. Chociaż niektóre osoby wykazują duże przywiązanie do miejsca, regionu, w którym zwykły żyć, i są niechętne do przemieszczenia się geograficznego bez względu na to, jak złe i niebezpieczne mogą być warunki tej egzystencji, to jednak wielu respondowanych przyznało, że nie byłoby w ogóle zainteresowanych wyjazdem zagranicznym, gdyby nie zmusiła ich do tego sytuacja polityczna i społeczna w ich kraju pochodzenia (Kim, 2015).

Ponadto badania prowadzone w krajach Ameryki Łacińskiej dowodzą, że te destynacje są postrzegane przez ekspatów-naukowców jako atrakcyjne ze względu na mniej stresogenne środowisko pracy, które pozwala na skoncentrowanie się i poświęcenie nauce i badaniom (Shin, Jung, 2013).

Zdaniem M. Kwieka (2015b), choć wsparcie i zachęty instytucjonalne są istotne, to jednak liczy się przede wszystkim podejście indywidualne. $\mathrm{Na}$ poziomie jednostkowym jednym $\mathrm{z}$ warunków wchodzenia $\mathrm{w}$ kontakt $\mathrm{z}$ innymi badaczami jest umiejętność poszukiwania, nawiązywania i utrzymywania relacji interpersonalnych w wymiarze międzynarodowym (Kocór i in., 2012). Kompetencja „relacyjności i uczestnictwa w sieci kontaktów społecznych", eksponowana w koncepcji ANT (actor network theory) oraz agentic turn (Kilduff, Brass, 2010), a także social network theory (Richardson, McKenna, 2014), odgrywa obecnie niebagatelną rolę we współpracy międzynarodowej i międzykulturowej. Determinuje ona szanse i rozwój kariery zawodowej ekspatriantów akademickich, a także przyczynia się do dyfuzji międzynarodowych norm i standardów w organizacjach (Nolan, 2011).

Wiele badań psychologów potwierdza, że predykatorem mobilności i chęci przemieszczania się z jednego kraju do innego jest motywacja osiągnięć. Składają się nań wiara we własne możliwości, większa mobilizacja do wysiłku po doznaniu porażki, skłonność do zakładania własnego biznesu, unikanie rutyny, innowacyjność, a także aktywne pozyskiwanie informacji i bycie "łowcą informacji” (tzw. infobroker).

Inne cechy, które pozytywnie korelują z dostosowaniem się i adaptacją w nowym miejscu pracy za granicą, to otwartość na doświadczenia, ekstrawersja (Caligiuri, 2000) oraz samoskuteczność. Ekspaci o wysokim poziomie poczucia własnej skuteczności mogą podejmować inicjatywy w celu rozwiązywania problemów i radzenia sobie z krytycznymi sytuacjami podczas międzynarodowych zadań, co może pomóc im w dostosowaniu się $\mathrm{w}$ kraju przyjmującym i poprawić ich wyniki (Claus i in., 2011). To istotne cechy tzw. „osobowości migranta” (migrant personality) (Boneva, Frieze, 2001) albo „mobilnej osobowości” (mobile personality), które determinują motywy podejmowania pracy za granicą metaforycznie ujęte w role architekta i eksplorera.

\section{Wyzwania i problemy ekspatriacji akademickiej}

$\square$ rwałą tendencją rozwoju szkolnictwa wyższego jest proces jego umiędzynarodowienia. W wielu krajach internacjonalizacja uczelni przyczynia się do zwiększonej mobilności społecznej (Altbach i in., 2010), a działając w sieci globalnej wymiany wiedzy, poza pełnieniem tradycyjnej misji edukacyjnej, staje się instrumentem wspierania rozwoju gospodarczego, wzmacniania konkurencyjności i innowacyjności gospodarki.

W odniesieniu do całego cyklu ekspatriacji, na który składa się etap preparacji, właściwego pobytu i repatriacji, można wskazać na kilka kwestii problematycznych, które powinny znaleźć wyraz w dalszych pogłębionych badaniach nad tą grupą pracowników, gdyż odnoszenie doświadczeń ekspatriantów akademickich do tych pozyskiwanych przez ekspatów biznesowych nie jest poprwane.

Na etapie preparacji wyjazdu ekspatrianckiego ważne są motywy indywidualne naukowca oraz ich zbieżność $\mathrm{z}$ celami uczelni macierzystej w zakresie strategii umiędzynarodowienia kadry. Chodzi tu o zdefiniowanie oczekiwań i warunków realizacji misji zagranicznej w obszarze naukowym, badawczym, dydaktycznym oraz organizacyjnym przez wszystkie strony kontraktu: uczelni macierzystej, jednostki przyjmującej i ekspatrianta. Określenie kryteriów rekrutacji i narzędzi selekcji umożliwiających wybór najwłaściwszej osoby na taki kontrakt również stanowi wyzwanie o charakterze organizacyjnym.

Niewątpliwą słabością cyklu ekspatriacyjnego jest brak wsparcia organizacyjnego i kulturowego dla akademików wysyłanych przez uczelnie za granicę, czego dowodzą nieliczne jak dotąd badania (Richardson, 2000). W przypadku naukowców na zagraniczne kontrakty wyjeżdżają ci, którzy zostali wybrani, spełnili wewnętrzne kryteria konkursowe. Jednak choć dany naukowiec jest "wybrany", to uczelnia nie zapewnia mu wsparcia w postaci przygotowania kulturowego (Trembath, 2016) i pomocy organizacyjnej. Chodzi m.in. o pomoc w doskonaleniu języka obcego, zapewnienie szkoleń kulturowych, zabezpieczenie godzin dydaktycznych podczas nieobecności akademika na macierzystej uczelni, zapewnienie ciągłości w zajęciach seminaryjnych dla prowadzonych doktorantów itp.

Problematyczny w czasie pobytu za granicą jest czas adaptacyjny, który pozwala na poznanie nowych warunków życia i pracy w innym kraju i przystosowanie się do nich. W tym obszarze występuje tzw. „paradoks rodziny ekspatrianta", który polega na tym, że z jednej strony wielu akademików podkreśla, iż brak rodziny polepsza ich zdolność do przystosowania się i pracy w obcym kraju, gdyż nie są dodatkowo obciążeni odpowiedzialnością 
za dobrostan współmałżonka czy dzieci. Z drugiej strony, akademicy, którzy posiadają rodzinę, przyznają, że ich zdolność adaptacji w obcym kraju jest znacząco wzmacniana przez obecność ich członków rodziny, którzy stanowią jedyny pewny i bezpieczny element $w$ nieznanym otoczeniu (Richardson, 2000).

$\mathrm{Na}$ etapie repatriacji, czyli powrotu $\mathrm{z}$ kontraktu do uczelni macierzystej, znaczącym problemem jest nieumiejętność wykorzystania przez Almae Matris potencjału nowych kompetencji i wiedzy, jaką pozyskał za granicą naukowiec. Chodzi o przełożenie owych doświadczeń na grunt lokalny, umożliwienie dzielenia się wiedzą, stworzenie roli mentora przygotowującego młodą kadrę do kariery międzynarodowej, zagospodarowanie „sieci relacji” (networkingu) z zagranicznymi naukowcami dla celów badawczych, dydaktycznych i organizacyjnych w uczelni macierzystej. Ta słabość jest znamienna także $\mathrm{w}$ odniesieniu do powracających menedżerów ekspatriantów (Przytuła, 2014).

\section{Podsumowanie}

l nternacjonalizacja stwarza wiele nowych i ekscytujących możliwości współpracy w ramach akademii i może być potężnym narzędziem do poprawy jakości i wprowadzania innowacji w jej kluczowych obszarach: badań, nauczania i służby publicznej.

Definicja ekspatrianta akademickiego zakłada, że jest to osoba o narodowości innej niż kraju goszczącego; zatrudnienie za granicą ma charakter długoterminowy, ale ograniczony $\mathrm{w}$ czasie; naukowiec podejmuje pracę $\mathrm{w}$ instytucjach szkolnictwa wyższego celem realizacji kształcenia, prowadzenia badań i spełniania zadań administracyjnych. Motywy, które skłaniają akademików do podejmowania misji zagranicznych, to przede wszystkim: ciekawość poznawcza, chęć rozwoju kompetencji badawczych i dydaktycznych, budowanie sieci relacji (networkingu) o zasięgu międzynarodowym, korzystniejsze warunki finansowe niż w kraju macierzystym.

Przedstawione $\mathrm{w}$ tym artykule zagadnienie ekspatriacji akademickiej z pewnością nie wyczerpuje tej tematyki, ani też nie dostarcza receptury na sukces misji zagranicznej naukowców. Niemniej charakterystyka tej specyficznej grupy pracowników międzynarodowych oraz wskazanie motywów skłaniających ich do pracy za granicą, może stanowić przyczynek do dalszych badań empirycznych zarówno w odniesieniu do polskiej, jak i zagranicznej perspektywy.

Po pierwsze, Ustawa z dnia 20 lipca 2018 r. - Prawo o szkolnictwie wyższym i nauce w Polsce nakłada poważne kryteria w zakresie umiędzynarodowienia kadry akademickiej i jest podstawą ewaluacji jednostek naukowych. Polska przechodzi właśnie najbardziej intensywne zmiany w swojej historii uprawiania nauki i musi dopasowywać swoje strategie do strategii dominujących w rozwiniętym świecie (Kwiek, 2015b). Warto podjąć dalsze badania analizujące wpływ tej reformy na poziom internacjonalizacji polskich naukowców, w szczególności na ich produktywność i widzialność polskiej nauki świecie.
Po drugie, doświadczenie ekspatrianckie ma wymiar indywidualny, gdyż jest to niewątpliwie „trampolina" do międzynarodowej kariery naukowca. Perspektywa jednostkowa dotyczy także osobowości ekspaty-akademika, jego postaw, zachowań i zdolności adaptacji do odmiennych uwarunkowań kulturowych, instytucjonalnych i relacyjnych. Z badań M. Kwieka wynika, że kadra akademicka w Polsce wykazuje odmienne akademickie zachowania i postawy niż ich europejscy i amerykańscy koledzy: pracuje inaczej i inaczej myśli o etosie swojej pracy (Kwiek, 2015a). Warto zatem dokonać analizy indywidualnych motywów i postaw polskich akademików-ekspatriantów i odnieść je do innych naukowców europejskich, którzy doświadczają podobnego etapu zmian w ich krajach.

Po trzecie, ekspatriacja akademicka to niewątpliwie korzyść dla uczelni wysyłających, które zyskują nową wiedzę, kompetencję, świeże i inne spojrzenie na pewne procesy, nowe doświadczenie i dostęp do sieci relacji z innymi naukowcami na świecie. To „know-how” powinno zostać właściwie zagospodarowane i wykorzystane we wszystkich obszarach funkcjonowania uczelni. Wypracowanie rozwiązań organizacyjnych, wspierających ekspatę przed i po powrocie, powinno stanowić kluczowy element polityki personalnej zorientowanej na umiędzynarodowienie własnej kadry. W optyce badań empirycznych powinny znaleźć się takie zagadnienia, jak: motywy ekspatriacji u akademików; formy adaptacji zawodowej, społecznej i kulturowej realizowane przez uczelnie wysyłające; planowanie i rozwój kariery naukowca międzynarodowego; repatriacja i zagospodarowanie potencjału wiedzy i doświadczeń zagranicznych ekspatrianta.

Po czwarte, należy też postawić pytanie o rolę i znaczenie międzynarodowych karier akademickich dla poszczególnych uniwersytetów i na wyższym poziomie - dla kondycji szkolnictwa wyższego w danym kraju. Chodzi tu o pomiar "miękkiej siły” (soft power) danego państwa i związane z tym zjawisko drenażu mózgów (brain drain; brain gain).

Jeśli internacjonalizacja ma być przyszłością szkolnictwa wyższego, to zrozumienie ekspatriacji akademickiej i opracowanie rozwiązań systemowych dla całego cyklu misji zagranicznej (preparacja, pobyt właściwy, repatriacja) będą miały coraz większe znaczenie dla uniwersytetów.

\section{dr hab. Sylwia Przytuła, prof. uczelni Uniwersytet Ekonomiczny we Wrocławiu Społeczna Akademia Nauk ORCID: 0000-0002-9602-241X e-mail: sylwia.przytula@ue.wroc.pl}

\section{Przypis}

1) Artykuł jest wynikiem realizacji działań $w$ ramach projektu INTEREKON „Regionalna Inicjatywa Doskonałości” prowadzonego w latach 2019-2022 (nr 15/RID/2018/19) i finansowanego przez MNiSW. 


\section{Bibliografia}

[1] Allen N., Meyer J. (1990), The Measurement and Antecedents of Affective, Continuance and Normative Commitment to the Organization, "Journal of Occupational Psychology", Vol. 63, pp. 1-18.

[2] Altbach P., Reisberg L., Rumbley L. (2010), Trends in Global Higher Education, UNESCO, Rotterdam.

[3] Boneva B., Frieze I.H. (2001), Toward a Concept of a Migrant Personality, „Journal of Social Issues”, Vol. 57, No. 3, pp. 477-491.

[4] Brewster C., Houldsworth E., Sparrow P., Vernon G. (2016), International Human Resource Management, CIPD, London.

[5] Brookfield Global Relocation Trends (2016), Global Mobility Trends Survey, New York, http://www.brookfieldgrs.com, access date: 12.09.2019.

[6] Caligiuri P. (2000), The Five Big Personality Characteristics as Predictors of Expatriates' Desire to Terminate the Assignment and Supervisor-rated Performance, „Personnel Psychology", Vol. 53, No. 1, pp. 122-141.

[7] Claus L., Lungu P.A., Bhattacharjee S. (2011), The Effects of Individual, Organizational Andsocietal Variables on the Job Performance of Expatriate Managers, „International Journal of Management", Vol. 28, No. 1(2), pp. 249-271.

[8] Domański T. (2017), Internacjonalizacja polskich uczelni wyższych, [w:] A. Domański, T. Stępień-Kuczyńska, A.Włodarska-Frykowska (red.), Internacjonalizacja polskich ośrodków politologicznych. Wydawnictwo Uniwersytetu Łódzkiego, Łódź, s. 63-80.

[9] Duan Y., Nie W., Coakes E. (2010), Identifying Key Factors Affecting Transnational Knowledge Transfer, „Information \& Management”, Vol. 47, No. 7-8, pp. 356-363.

[10] Flisi S., Meroni E.C., Vera-Toscano E. (2016), Educational Outcomes and Immigrant Background, Whirte Publishing, Luxembourg.

[11] Gao Y., Baik C., Arkoudis S. (2015), Internationalization of Higher Education, [in:] D. Souto-Otero, M. Huisman, J. Boer, H. Dill (eds.), The Palgrave International Handbook of Higher Education Policy and Governance, Palgrave Macmillan, London, pp. 300-320.

[12] Henard F., Diamond L., Roseveare D. (2012), Approaches to Internationalization and Their Implications for Strtaegic Management and Institutional Practice, IMHE, Paris, www. oecd.ord/edu/imhe, access date: 12.09.2019.

[13] IOM (2018), World Migration 2018, International Organization for Migration, Geneva.

[14] Isakovic A.A., Whitman M. (2013), Self-initoiated Expatriate Adjustment in the United Arab Emirates: a Study of Academics, „Journal of Global Mobility”, Vol. 1, No. 2, pp. 161-186.

[15] Kilduff M., Brass D.J. (2010), Organizational Social Network Research: Core Ideas and Key Debates, „The Academy of Management Annals", Vol. 1, pp. 123-145.

[16] Kim E.C. (2015), International Professors in China: Prestige Maintenance and Making Sense of Teaching Abroad, „Current Sociology”, Vol. 63, No. 4, pp. 604-620.

[17] Kmiotek K. (2019), Różnorodność pracowników w odniesieniu do zaangażowania - impresje z Arabii Saudyjskiej, [w:] S. Przytuła (red.), Zarządzanie różnorodnością pracowniów. Perspektywa globalnej mobilności i migracji., Wyd. Naukowe PWN, Warszawa, s. 171-181.

[18] Kocór M., Strzebońska A., Keler K. (2012), Kogo chca zatrudniać pracodawcy? Wyd. Naukowe PWN, Warszawa.

[19] Kwiek M. (2015a), Młoda kadra: różnice międzypokoleniowe w pracy naukowej i produktywności badawczej. Czym Polska różni się od Europy Zachodniej? CPP RPS Vol. 87, Center for Public Policy Studies, „Research Papers”, https:// repozytorium.amu.edu.pl/bitstream/10593/13834/1/CPP RPS_vol.87_Kwiek.pdf, data dostępu: 12.09.2019 r.

[20] Kwiek M. (2015b), Uniwersytet $w$ dobie przemian, Wyd. Naukowe PWN, Warszawa.

[21] Kwiek M. (2018), Changing European Academics A Comparative Study of Social Stratification, Work Patterns and Research Productivity, Taylor\&Francis, New York, London.

[22] Lauring J., Selmer J. (2015), Job Engagement and Work Outcomes in a Cognitively Demanding Context, „Personnel Review", Vol. 44, No. 4, pp. 629-647.

[23] Mc Nulty Y., Brewster C. (2017), Theorizing the Meanin$g(s)$ of 'Expatriate': Establishing Boundary Conditions for Business Expatriates, „The International Journal of $\mathrm{Hu}$ man Resource Management", Vol. 28, No. 1, pp. 27-61.

[24] Mc Nulty Y., Brewster C. (2019), Working Internationally. Expatriation, Migration and Other Global Work, Edward Elgar Publishing, Cheltenham.

[25] Nolan J. (2011), Good Guanxi and Bad Guanxi: Western Bankers and the Role of Network Practices in Institutional Change in China, „Journal of Human Resource Management", Vol. 22, No. 16, pp. 3357-3372.

[26] OECD (2002), International Mobility of the Highly Skilled, Paris.

[27] Przytuła S. (2014), Zarzq̨dzanie kadra ekspatriantów $w$ filiach przedsiębiorstw międzynarodowych $w$ Polsce, CeDeWu, Warszawa.

[28] Przytuła S. (2018), Inicjatywa i intencjonalność w podejmowaniu misji zagranicznej przez ekspatriantów $z$ własnej inicjatywy (SIE), „Organizacja i Kierowanie”, Vol. 4, $\mathrm{Nr} 183$, s. 169-184.

[29] Richardson J., McKenna S. (2014), Towards an Understanding of SOCIAL NETWORKS among organizational Self-initiated Expatriates: A Qualitative Case Study of a Professional Services Firm, „International Journal of Human Resource Management", Vol. 25, No. 19, pp. 2627-2643.

[30] Richardson J. (2000), Expatriate Academics in the Globalized Era: The Beginnings of an Untold Story? „Asia Pacific Business Review", Vol. 7, No. 1, pp. 121-150.

[31] Roberts D. (2015), Expatriate Workers in International Higher Education, „Journal of College and Character", Vol. 16, No. 1, pp. 37-43.

[32] Romanowski M., Nasser R. (2014), Identity Issues: Expatriate Professors Teaching and Researching in Quatar, „Higher Education”, Vol. 69, No. 4, pp. 653-671.

[33] Selmer J., Lauring J. (2011), Marital Status and Work Outcomes of Self-initiated Expatriates. Is there a Moderating Effect of Gender? „Cross Cultural Management: An International Journal”, Vol. 18, pp. 198-213. 
[34] Selmer J., Lauring J. (2012), Reasons to Expatriate and Work Outcomes of Self-initiated Expatriates, „Personnel Review", Vol. 41, No. 5, pp. 665-684.

[35] Selmer J., Lauring J. (2009), Cultural Similarity and Adjustment of Expatriate Academics. „International Journal of Intercultural Relations”, Vol. 33, No. 5, pp. 429-436.

[36] Selmer J., Trembath J.L., Lauring J. (2017), Expatriate Academics: An Era of Higher Education Internationalization, [in:] Y. Mc Nulty, J. Selmer (eds.), Research Handbook of Expatriates, Elgar, Cheltenham, pp. 158-179.

[37] Shin J.C., Jung J. (2013), „Academics” Job Satisfaction and Job Stress across Countries in the Changing Academic Environments, „Higher Education”, Vol. 67, No. 5, pp. 603-620.

[38] Sulkowski Ł.,Przytuła S., Migdal A. (2019), Ukrainian Skilled Migrants in Polish Emerging Economy - Implications for Knowledge Management, „European Journal of International Management”, https://doi.org/10.1504/ EJIM.2020.10022507, access date: 12.09.2019.

[39] Sułkowski Ł. (2018), Fuzje uczelni, Wyd. Naukowe PWN, Warszawa.

[40] Top Universities (2018), www.topuniversities.com, access date: 12.09.2019.

[41] Trembath J. (2016), The Professional Lives of Expatriate Academics: Construct Clarity and Implications for Expatriate Management in Higher Education, "Journal of Global Mobility", Vol. 4, No. 2, pp. 112-130.

[42] Volk S., Kohler T., Pudelko M. (2014), Brain Drain: The Cognitive Neuroscience of Foreign Language Processing in Multinational Corporations', „Journal of International Business Studies”, Vol. 45, pp. 862-865.

\section{Academic Expatriation as a Sign of Academia's Internationalisation}

\section{Summary}

Internationalisation of academia is prompting more and more scientists to work abroad. They are so-called academic expatriates who combine the features of the widely studied group of highly qualified expatriates and scientists. The criteria defining this group of international employees are as follows: scientist's nationality is different from that of the host country; employment is long-term but limited in time (contract); scientist undertakes a foreign mission to implement the basic pillars of the academy, i.e. teaching, conducting research and performing public service in the form of administrative activities. The key motives for undertaking a foreign mission by academics are: cognitive curiosity, better career opportunities and conducting scientific research; a positive institutional climate at host universities, favourable financial conditions as well as an external necessity, i.e. escape from the home country driven by lack of career opportunities on the local academic labour market and a threat of war and repression.

\section{Keywords}

academic expatriation, expatriate, migrant, internationalisation 